УДК: 373.3.016:51

DOI:

Владислав Сарієнко, кандидат педагогічних наук, доцент кафедри природничо-математичних дисииплін та інформатики у початковій освіті ДВНЗ “Донбаський державний педагогічний університет”

\title{
ПРО КОРЕКТНЕ ВИКОРИСТАННЯ ТЕРМІНОЛОГЇ̈ ПРИ ВИВЧЕННІ ВЕЛИЧИН У ПОЧАТКОВІЙ ШКОЛІ
}

У статті розглядається актуальне питання з інформативного компоненту методики вивчення величин у початковій школі-коректне використання термінології. Звертається увага на проблеми визначення поняття “величина” та на наслідки термінологічних помилок, які з цьього випливають. Як на спосіб виправлення циих помилок, звертається увага на чисельні дослідження вчених, які зазначають два значення поняття загальнонаукове і предметне, та наводяться коректні формулювання означень величин, які вивчаються у початковій школі.

Ключові слова: величина; термінологія; означення; мовлення; навчальний процес; початкова школа; вимірювання; обчислення.

Jim. 11.

Vladyslav Sariyenko, Ph.D.(Pedagogy),Associate Professor of the Natural and Mathematical Sciences and Informatics in Primary Education Department State Pedagogical University "Donbas State Pedagogical University"

\section{ABOUT THE CORRECT USAGE OF TERMINOLOGY DURING STUDYING DIMENSIONS AT PRIMARY SCHOOL}

The notion "Dimension" is one of system-forming lines of Mathematic course at primary school. In the article it is mentioned, that the idea and notion formation of dimensions and their calculating practically goes beyond Math course and has general cultural value, because imagination and notion data are widely used in studying other subjects, in familiarization the child with surrounding world and further in the practice of the adult. This fact is a reason of polysemy of this notion, that is a turn of different ways of its notion and makes difficulties both in the awareness of the notion dimension and in the methods of its teaching. The result of such variegated is the mixing of notions, that contradict one another and so break the correctness of terminology, that corresponds the real content of the theory of dimension notion, in fact, that is the actuality of the work.

In the article, on the basis of the world level scientists' researches, the notion of dimension is studied in two meanings - general scientific and substantive. It is mentioned, that in general scientific sense "dimension" is the object property to be measured, namely compared with another object of the same plurality. In this sense the expression "dimension of size" is correct. In substantive meaning "dimension" is the characteristics of the object's property, that is signified in units (measure). In this sense the notion dimension means giving quantitative characteristics of the measured object. That's why the expression "calculating of dimension" is correct here.

In the article the essence of scalar quantities is described, the description of measuring procedure is done and on its basis the content of the dimension definition as the unit of object is defined. According to this, in the article the terminology accordingly the objects' measuring and calculating their dimensions is corrected, the definitions of the dimensions, that are studied at primary school, namely length, square, size, mass, time are given in the correct form.

As a result, a unique opportunity of the correct attitude toward the terminology both in formulation Mathematic notions, relations and in usage in practice are marked.

Keywords: dimension; terminology; definition; speech; learning process; a primary school; measurement; calculation.

A ктуальність. Сучасна система початкової освіти, яка створена В. Давидовим, М. Моро, Д. Ельконіним,А.Пишкало,Н.Виноградовою, Л. Занковим, Н. Істоміною, Л. Петерсон та іншими вченими, характеризується варіативністю концепцій, технологій, методичних і методологічних систем і підходів до процесу навчання.

Розвиток молодших школярів під час навчання математики в значній мірі залежить від засвоєння ними таких спеціальних понять, якими є поняття числа і величини, поняття геометричної фігури та ін. Ці поняття $є$ основними для формування сучасних уявлень про світ і для практичної діяльності, тому їх вже в початковій школі слід вивчати в більш багатосторонньому і одночасно більш абстрагованому вигляді, коли мова заходить про застосуванні математики до явищ навколишнього світу. 


\section{ПРОКОРЕКТНЕ ВИКОРИСТАННЯТЕРМІНОЛОПЇ ПРИ ВИВЧЕННІ ВЕЛИЧИН У ПОЧАТКОВІЙШКОЛІ}

Методико-математична підготовка вчителя початкової школи є однією з головних задач підвищення якості навчання, яке залежить від процесу проектування практики навчання, який передбачає обгрунтування цілей і завдань навчання, вибір об'єктів вивчення і видів діяльності для розробки ефективних методів навчання.

Аналіз існуючих програм різних освітніх ліній початкової школи показує, що поняття величини $\epsilon, 3$ одного боку, сполучною ланкою між абстрактними уявленнями учнів і реальним світом, а з іншого - загальнонауковим поняттям, і тому може бути покладено в основу професійної підготовки вчителів початкової школи.

Формування загальнонаукових понять $\epsilon$ складним процесом послідовного розкриття якісних і кількісних особливостей предметів і явищ навколишнього світу. Кожне поняття має свій термін і свою дефініцію (означення), яка чітко окреслює його значення. У цій дефініції відображаються усі істотні ознаки поняття.

Термінологія кожної галузі знань будується на основі понятійних зв'язків професійних знань. Отже, термінологія, як системний набір термінів, обмежує та вербально закріплює систему понять тієї чи іншої галузі знань. За словами А. Реформатского, “Термінології і терміни $є$ інструментом, за допомогою якого формуються наукові теорії, закони, принципи, положення" [7, 88]. Особливість математичної термінології полягає в її однозначності, тобто, кожний термін має лише одне значення і позначає лише одне поняття i навпаки, кожному поняттю відповідає лише один термін. Ця особливість зумовлює найвищий рівень відповідальності за використання термінів. Тут не допускається зміна змісту дефініції, зміна форми допускається як вимушене виключення, скажімо, уметодичних цілях, але при цьому зміст поняття не повинен змінюватись. Він повинен буги еквівалентним науковому. Довільне трактування термінів неприпустиме, оскільки зміна іноді не тільки слова, а й букви в ключовому слові може впливати на зміст терміну. Чітке дотримання зазначених правил використання термінології $\epsilon$ однією з головних умов розвитку математичного мислення і математичного мовлення. На відміну від математичної галузі, термінології інших галузей, особливо мовних, у більшості своєї багатозначні, мають низку синонімів.

Учні не одразу опановують поняттям, а поступово засвоюють його зміст, обсяг, зв'язки і відношення з іншими поняттями.

Традиційно в практиці навчання математики в початковій школі матеріал з величин вважається найбільш важким для засвоєння учнями. Причиною такого явища $\epsilon$, по-перше, високий рівень абстрактності цього поняття, а по-друге, неоднозначність визначення поняття “величина" в різних наукових джерелах. Тому в навчальному процесі в початковій школі поняття величини в свідомості учнів формується без визначення в процесі виконання ними практичних завдань, пов'язаних 3 вимірюванням і заснованих на спостереженнях, на особистому життєвому досвіді учнів. Учитель тут, на початкових етапах формування поняття величини, спирається на інтуїцію учнів.

Формування уявлень, а потім і понять про величини та їх обчислення практично виходить за межі курсу математики i має загальнокультурне значення, оскільки дані уявлення та поняття широко використовуються при вивченні інших навчальних предметів, при ознайомленні дитини з навколишнім світом, а далі й у практичній діяльності дорослої людини. Цей факт $є$ причиною багатозначності цього поняття, що в свою чергу є витоком різних варіантів його визначення. Наприклад, У словнику С. Ожегова "Величина - це те (предмет, явище $і$ m.n.), щэо можна виміряти, обчислити. Нескінченно мала величина, рівні величини". Н. Віленкин описує величину, як властивість певної множини об'єктів, на якій визначена операція вимірювання. У Великій Радянській Енциклопедії "Величина - ие математичне поняття, яке описує об'єкти, для яких може бути визначено відношення нерівності та суть операціi додавання, а також виконується низка властивостей, включаючи аксіоми Архімеда $і$ неперервності". У Сучасній Енциклопедії: "Величина - ие узагальнення конкретних понять: довжини, площі, маси та ін.”. У Тлумачному словнику С. Кузнєцова: “Величина - ие розмір (об'єм, площа, протяжність та ін.) якогось об'єкта, предмета, щзо має видимі фізичні межі". А таке визначення величини ми читаємо у Математичній енциклопедії: “Величина - одне з основних математичних понять, що виникло як абстракиія від числових характеристик фізичних властивостей. Поняття величини в математиці поряд з поняттями множини, неперервності та ін. може розглядатися як уточнений вираз категорії кількості". Усього формулювань більше 10.

Як бачимо, особливістю поняття “величина" $\epsilon$ строкатість його визначення, що тягне за собою низку термінологічних помилок. Такий стан створює значні труднощі як в усвідомленні та 


\section{ПРОКОРЕКТНЕ ВИКОРИСТАННЯТЕРМІНОЛОПЇ ПРИ ВИВЧЕННІ ВЕЛИЧИН У ПОЧАТКОВІЙШКОЛІ}

засвоєнні поняття величини, так і в методах його викладання. Результатом такої строкатості $\epsilon$ змішування понять, які суперечать одне одному. Зокрема, у практиці роботи сучасної початкової школи не розмежовуються поняття “число”, “величина”, “міра”. Це призводить до того, що учні, студенти, нерідко і вчителі ототожнюють такі поняття, як “площа”, “поверхня” і “площина”, “площа прямокутника” i “прямокутник”, порівнюють числа “за їх величиною”, креслять “величину відрізка", “вимірюють величину маси” i т. д. Таким чином, властивості величин приписуються об'єктам, які їх не мають. Студенти, учні і навіть учителі часто неправильно користуються термінами “величина”, “число”, “кількість”, “значення величини”: бачать один і той же зміст в термінах “величина” і “кількість”; говорять про “величину часу”, про “вимір площі фігури”; вживають словосполучення “збільшити величину”, “побудуй величину”, “покажи величину”; використовують термін “величина числа" і т.д. Уся ця плутанина виникає в результаті некоректного використання адекватної до цього поняття термінології

Отже, уточнення змісту поняття “величина” $\mathrm{i}$ упорядкування відповідної термінології є вельми актуальним для виправлення зазначених помилок.

Аналіз останніх досліджень. Як свідчить наука, поняття “величина" $\epsilon$ одним 3 фундаментальних загальнонаукових понять, яке виходить далеко за межі математики. Саме тому дослідженню цього поняття, його місця в різних наукових галузях, а отже й у математиці вченими присвячено велика кількість робіт. Перші відомості про величини, як основу математичних відношень представлені ще у працях Аристотеля (Метафізика), Евклідом (Начала), Евдоксом. Значний внесок в дослідження цього поняття був зроблений роботах Кавальєрі. Його ідея щодо методу вимірювання площ полягає в порівнянні даної фігури з відомою площею - з іншою фігурою, площа якої теж відома. Теорія Кавальєрі отримала завершення в працях Г. Лейбніца та І. Ньютона.

У 18 та 19 століттях питання обгрунтування теорії величин отримують подальший розвиток у роботах математиків Лапласа, Лагранжа, д’Аламбера, Мешана, Фаркаша Бойяі та ін.

Найбільш вагомі дослідження поняття величини викладені в роботах науковців XX століття А. Лебега [5], В. Кагана [2], А. Колмогорова [3]. У роботах цих авторів сформульоване найбільш адекватне означення поняття “величина”, визначена система аксіом, сформульовані й доведені властивості величин, визначена логічна структура і супідрядність видів величин.

На сучасному етапі поряд 3 дослідженнями фундаментальних властивостей поняття “величина" (I. Депман, М. Джеммер, Є. Ляпін) значне місце посідають методичні розробки щодо вивчення цього поняття у школі, оскільки у шкільному курсі математики це поняття разом 3 поняттям числа складає одну 3 головних змістових ліній як арифметики у початковій школі, так і геометрії в усіх ланках шкільного навчання, а також при вивченні природничих дисциплін (фізики, хімії, географії) у середній та старшій ланках. Зокрема, цьому напрямку присвятили свої дослідження О. Митник, А. Тихоненко, А. Ткачов, М. Урбан та інші. Так О. Митник [6] досліджує питання особливостей розкриття змісту поняття молодшим школярам. Л. Стойлова [8] та А. Тихоненко [9] - методику навчання молодших школярів видам скалярних величин (довжина, площа, маса, об'єм, час та ін.). М. Урбан [11], досліджував вивчення маси та системи одиниць її обчислення на основі загальної моделі для групи основних величин.

Однак проблемним питанням практично в усіх методичних дослідженнях залишається питання коректного використання термінології, яке тягне за собою проблеми усвідомлення і засвоєння як поняття величини у цілому, так і конкретних величин зокрема. Саме це і $є$ причиною того, що змістова лінійка величин представляється найбільш важкою у навчальній практиці.

Для виявлення інваріантного змісту поняття слід уточнити, в якому значенні вживається термін “величина" в професійному мовленні вчителя, як пов'язані між собою поняття “величина” i “число” і як необхідно користуватися цим терміном в різних ситуаціях. Розкриття цих питань і є метою нашої статті.

Виклад основного матеріалу. У процесі сучасної науково-методичної роботи велика увага звертається на теоретико-методологічні основи викладання математики за науково-педагогічним спрямуванням “Інтелект України”, що формує у вчителів теоретичну готовність до імплементації в практичній роботі початкової школи основних фундаментальних та методичних положень на компетентнісній основі.

Вивчення величин у початковій школі обмежується множиною скалярних величин, тобто таких, які характеризуються лише числовим значенням. Векторні величини представлені лише швидкістю. Обчислення скалярних величин на основі вимірювання кардинально впливає на розвиток молодших 


\section{ПРОКОРЕКТНЕ ВИКОРИСТАННЯТЕРМІНОЛОПЇПРИ ВИВЧЕННІ ВЕЛИЧИН У ПОЧАТКОВІЙШКОЛІ}

школярів. Це обумовлене тим, що через поняття величини описуються реальні властивості предметів і явищ оточуючої дійсності, а знайомство з залежностями між величинами допомагає створити у дітей цілісне уявлення про навколишній світ. Вивчення процесу вимірювання та знаходження значення величини сприяє формуванню практичних умінь та навичок, які необхідні в повсякденному житті. Крім того знання та уміння, про величини, які діти отримали в початкових класах, $є$ основою для подальшого вивчення математики в середній та старшій ланках школи.

Для виявлення і розгляду термінологічних особливостей поняття величини логічним $€$ визначення його логіко-структурного змісту.

Аналіз усіх наведених вище означень величини, представлених різними довідковими джерелами засвідчує, що спільним елементом усіх їх $\epsilon$ наявність операції вимірювання. Визначимо поняття вимірювання на прикладі відрізків.

Нехай задані два відрізка $\boldsymbol{a}$ i $\boldsymbol{b}: \boldsymbol{a} \boldsymbol{b}$.

Порівняємо ці два відрізка, наклавши відрізок $\boldsymbol{b}$ на відрізок $\boldsymbol{a}$. Нехай він цілком вкладеться на відрізку $\boldsymbol{a} k$ разів. За домовленістю поставимо у відповідність відрізку $\boldsymbol{b}$ число $\mathbf{1}$, назвемо його міркою і позначимо буквою $\boldsymbol{e}$, тобто $\boldsymbol{e}=1$. Отже, отримаємо $\boldsymbol{a}=k \cdot \boldsymbol{e}$. Цей добуток $-k \cdot \boldsymbol{e}$, називається мірою. Він складається 3 числа $n$, помноженого на мірку $е$. Ця міра в узагальненому розумінні і $\epsilon$ величина. Для множини відрізків ( $\boldsymbol{a}$ і $\boldsymbol{e}$-відрізки) ця міра називається довжиною, для множини поверхонь ( $\boldsymbol{a}$ і $\boldsymbol{e}-$ поверхні) - площею, для ємностей - об'ємом, для певної кількості речовини - масою і т.д. Сам же процес встановлення співвідношення міри і мірки називається вимірюванням.

Підсумовуючи розглянутий факт, можна зробити висновок:

Вимірюванням називається порівняння 2$x$ елементів певної множини, одному з яких за домовленістю ставиться у відповідність число 1.

Розглядаючи співвідношення міри і мірки, слід зазначити, що оскільки мірка вибирається за домовленістю, то вона може представлятися як змінний елемент. Елемент $\boldsymbol{a}$ сам по собі не змінюється. А при зміні мірки $\boldsymbol{e}$ на більшу або меншу змінюється число $k$, яке стоїть у добутку перед міркою. Тому в загальному вигляді формула вимірювання виглядає як $\boldsymbol{a}=k \cdot \boldsymbol{e}$. Отже, у множині певних об' єктів міра (величина) представляється як числова характеристика цих об'єктів. Число $k$, яке стоїть у добутку, називається числовим значенням величини. Це числове значення $k 3$ міркою $\boldsymbol{e}$ знаходяться в обернено пропорційному відношенні: у скільки разів збільшується (зменшується) мірка, у стільки ж разів зменшується (збільшується) числове значення величини.

Для виявлення інваріантного змісту поняття “величина" слід уточнити, в якому значенні вживається термін “величина" в професійному мовленні вчителя, як пов'язані між собою поняття “величина" $i$ “число” $і$ як необхідно користуватися цим терміном в різних ситуаціях.

Поняття величини, як й інші поняття математики, формувалося поступово в результаті абстрагування від якісних особливостей властивостей реальних об'єктів. Тому величина - це не сама реальність, а відображення властивостей об'єктів навколишньої дійсності. У практиці під величиною зазвичай розуміють не самі елементи множини, а поняття, введене для розрізнення критеріїв порівняння об'єктів изих множин. Так виникають поняття “об'єм”, “маса", “час", “температура" та ін. Тому вчитель повинен чітко уявляти і доводити до свідомості учнів, що довжина відрізка - це число, яке характеризує даний відрізок з кількісної сторони. То є міра відрізка, а сам відрізок - це частина прямої; прямокутник - фігура, геометричний образ, а площа прямокугника - число, що його характеризує (міра). I т.д.

Отже, за визначенням В. Кагана, “Величиною А називається загальна властивість елементів певної множини $M=\{a, b, c, \ldots, k\}$, між якими існує відношення рівності $i$ нерівності" [3].

3 цього означення випливають два значення поняття “величина":

1-е значення. Під поняттям “величина" розуміється властивість об'єкта бути виміряним, тобто порівняним з іншим об'єктом цієї ж множини. Саме в цьому сенсі досліджується поняття величини в роботі А. Лебега “Вимірювання величин” [5]. В цьому значенні поняття величини розглядається як родове поняття, яке має загальнонауковий смисл.

2-е значення. "Величина" - це характеристика об'єкта, виражена в одиницях виміру (міра).

У цьому значенні слово “величина" вживається для вираження числового значення величини як властивості предметів: для відрізків - довжина, для поверхонь - площа, для ємностей - об ' $є м$, для упорядкування подій - час, для руху - швидкість та ін. У цьому значенні термін “величина" є видовим поняттям відносно до загального (родового), представленого у першому значені, тобто, “довжина”, “площа”, 


\section{ПРОКОРЕКТНЕ ВИКОРИСТАННЯТЕРМПНОЛОПЇ ПРИ ВИВЧЕННІ ВЕЛИЧИН У ПОЧАТКОВІЙ ШКОЛІ}

“маса”, “час", “швидкість”, “робота”, “сила”, “тиск” та інші $€$ видовими поняттями загальнонаукового родового поняття “величина".

Як зазначає Л. Стойлова $[8,424]$, властивість мати довжину, стосується об'єктів певного класу, а саме, відрізків. Аналогічно й для об'єктів іншого роду, наприклад, для поверхонь - мати площу. У той же час, ці об'єкти в межах однієї множини можна порівнювати, тобто, вимірювати, про що свідчить друга частина означення - між ними можна встановити відношення рівності і нерівності. У процесі вимірювання встановлюється кількісна характеристика зазначеної величини.

3 наведеного визначення випливають два термінологічні наслідки. Суть їх полягає в тому, що математичне розуміння терміна "величина" часто підміняється уявленням про кількісну характеристику величини. Поняття “площа”, “довжина", “маса", “об'єм” та інші є видовими поняттями загального родового поняття “величина”. Тому, коли йдеться про вимірювання величини, то мається на увазі, що вимірювання стосується загальної властивості об'єкта - бути виміряним. Коли ж мова йде про знаходження числового значення видового поняття, наприклад, довжини відрізка або площі поверхні, то тут визначальним є вже термін не “вимірювання" довжини відрізка (площі поверхні), а “обчислення” довжини відрізка (площі поверхні фігури). Саме ж обчислення $є$ не що інше, як знаходження міри об'єкта. Отже, коректною буде саме така термінологія, а терміни: “величина часу”, “вимір площі фігури” замість обчислення; словосполучення: “покажи величину”, “величина числа”, “величина маси” “виміряйте довжину”, “виміряйте площу” та ін. не є коректними. Вимірюється відрізок, а довжина обчислюється, тобто, характеризується числом. Вимірюється поверхня, а площа обчислюється. Вимірюється речовина, а маса обчислюється. Аналогічно й щодо інших величин. Такий от мовний тезаурус вживання терміна “величина".

Як бачимо, загальне поняття величини є поняттям високого рівня абстракції, який учням початкової школи ще не досяжний. Тому воно розглядається у початковому курсі математики у другомузначенні, а саме, у розумінні визначення числового значення властивості об'єкта, тобто міри.

Отже, виходячи 3 цього, а також із загального означення величини, поданого вище, можна (у другому значенні) сформулювати означення деяких величин так: “Довжиною називається міра відрізка [10] (мірка- одиничний відрізок)”.
Це розуміється так: є відрізок, який треба виміряти, й інший, який ми приймаємо за одиницю вимірювання, тобто ставимо йому у відповідність число 1 (мірка). Шляхом порівняння встановлюється міра, тобто числова характеристика вимірюваного відрізка у порівнянні з міркою. Ця міра (число з вказаною міркою) і є довжина. До речі, такої ж позиції дотримується й група авторів навчального посібника "Математика" [1,509].

За аналогією:

Площею називається міра поверхні (мірка - одинична поверхня).

Об’ємом називається міра місткості певної ємності (мірка - одинична ємність).

Maca. Означення цієї величини дослівно сформульоване І. Ньютоном як міра кількості матерії, що міститься в речовині (мірка кількість речовини, що знаходиться в стані покою і має певнущільність та вагу). Пізніше І. Ньютоном у фізичному значенні маса була визначена як міра iнертності miла. Інше визначення маси для учнів початкової школи, які ще не знають понять “інерція”, “матерія”, доцільно вживати просто термін “речовина”, тобто: Масою називається міра кількості речовини об'єкта (тіла, рідини)

Час - міра чергування подій (мірка одиничний інтервал між двома певними подіями).

Вартість - міра грошового еквіваленту речі (послуги) (мірка- грошовий еквівалент одиниці речі або послуги, тобто - ціна) [10].

У початкових класах окрім зазначених величин вивчають ще такі як кількість - міра наявності об'єкта у множині; на уроках природознавства діти знайомляться 3 температурою, як мірою теплового стану речовини (мірка - певний фіксований тепловий стан певної речі, наприклад, момент переходу води у твердий стан або газоподібний) та ін.

В контексті наведеного означення поняття величини іншим фактом, який потребує коректування, є визначення поняття “довжина" i “площа”, викладені в деяких підручниках [8] та посібниках [9], а також в інтернетних виданнях. Довжина відрізка в них формулюється таким чином: Довжиною відрізка називається додатна величина, щзо має наступні властивості:

1) рівні відрізки мають рівні довжини;

2) якщо відрізок складається $з$ двох відрізків, то його довжина дорівнює сумі довжин його частин $[9,406]$.

Аналогічно формулюється й означення площі: Площею фігури називається додатна величина, щзо має наступні властивості: 
1) рівні фігури мають рівні площі;

2) якщо фігура складається з двох фігур, то їі площа дорівнює сумі площ його частин $[8,408]$.

Щоб усвідомити таку форму означення, звернемося до загально відомої логіки опису поняття. Описати поняття - значить розкрити його зміст через ознаки, які притаманні лише цьому поняттю. При цьому одним з правил означення поняття $є$ таке: “Означення не повинно робити кола”. Це правило вимагає, щоб “поняття, яке визначається, не визначалось через поняття, яке само робиться зрозумілим тільки через поняття, яке визначається" [5].

Зміст означень, які ми тут розглядаємо, тяжіє до форми так званих аксіоматичних визначень, які у свою чергу $є$ частковим випадком контекстуальних визначень. Аксіоматичне означення $є$ фундаментальним і будується із суджень, як кон'юнктивна сукупність тверджень, які містять поняття, що визначається, і яке визначає в цих твердженнях.

Логіка зазначає, що контекстуальні визначення завжди залишаються значною мірою неповними і нестійкими. Не ясно, наскільки широким повинен бути контекст, познайомившись 3 яким, ми засвоїмо значення слова, яким позначається поняття. Ніяк не визначено також те, які саме інші поняття можуть або повинні входити в цей контекст.

Аксіоматичне означення відноситься до найвищого рівня складності за рівнем абстрагування і вимагає додаткового опису властивостей, які з нього випливають. У той же час логіка контекстуальних означень не дає чіткої відповіді на використання одного й того ж терміну в тексті означення. Тому, на наш погляд, наведені нами означення цих же понять довжини і площі як міри відрізка і міри поверхні, які грунтуються на понятті вимірювання, є більш коректними i зрозумілими. Тим більше в теоретичних основах початкового курсу математики. Це ж стосується й означень інших величин.

Висновок. 3 викладеного у статті випливає виключна важливість коректного відношення до термінології як при формулюванні математичних понять і відношень, так і при вживанні у практичній діяльності. Кожний термін має чітко однозначний зміст і його вільне трактування формує в учнів викривлене розуміння про зміст об'єктів пізнання,їх класифікацію, логіко-структурну супідрядність, сугність практичного використання, породжує істотні перепони в розвитку математичного мислення і мовлення.

\section{ЛІТЕРАТУРА}

1. Затула Н. I., Зуб, А. М., Копернік, Г. І.,
Нещадим А. Ф. Математика : навчальний посібник. Київ, 2006. 560 с.

2. Каган В. Ф. Очерки по геометрии. Москва, $1963.572 \mathrm{c}$.

3. Колмогоров А. Н. Величина. БСЭ, Т. 4. 3-е узд. Москва. 1971. С. 113.

4. Контекстуальне визначення. URL: $\underline{\mathrm{http}: / /}$ Studopedia.su/1_15837.

5. Лебег А. Вимірювання величин. Москва, $1960.204 \mathrm{c}$.

6. Митник О. Я., Сарієнко В. К. Величини: особливості розкриття змісту поняття молодшим школярам. Учитель початкової школи. №3. 2018. C. $18-22$.

7. Реформатський А. Термин как член лексической системы языка. Проблемы структурной лингвистики. Москва, 1968. С. 88.

8. Стойлова Л. П. Математика : Учебник для студ. высш. учеб. завед. Москва, 1999.320 с.

9. Тихоненко А. В. Изучение понятия величины в начальной школе.Таганрог, 2009. 268 с.

10. Тихоненко А. В., Сарієнко В. К. Величини у початковій школі : навч.-метод. посібник /за заг. ред. В. К. Сарієнка. Слов'янськ. 152 с.

11. Урбан М. А. Изучение массы и системы единиц измерения массы на основе общей для группы основных величин модели. Начальная школа. № 11. 2009. С. 22 - 28.

\section{REFERENCES}

1. Zatula, N. I., Zub, A. M., Kopernik, G. I. \& Neshhadym, A. F. (2006). Matematyka : navchalnyi posibnyk [Mathematics: a tutorial]. Kyiv, 560 p. [in Ukrainian].

2. Kagan, V. F. (1963). Ocherky po geometry [Essays on geometry]. Moscow, 572 p. [in Russian].

3. Kolmogorov, A. N. (1971). Velychyna [Value]. Moscow, Vol. 4, p. 113. [in Russian].

4. Kontekstualne vyznachennya [Contextual Definition]. Available at: http://Studopedia.su/ 1 15837. [in Ukrainian].

5. Lebeg, A. (1960). Vymiryuvannya velychyn [Measurement of quantities]. Moscow, 204 p. [in Russian].

6. Mytnyk, O.Ya.\& Sarienko, V. (2018). Velychyny: osoblyvosti rozkryttya zmistu ponyattya molodshym shkolyaram [Values: features of the disclosure of the concept of the concept of junior schoolchildren]. Elementary school teacher, No 3, pp. 18 - 22. [in Ukrainian].

7. Reformatskyj, A. (1968). Termyn kak chlen leksycheskoj systemy yazyka [The term is a member of the lexical language system]. Problems of Structural Linguistics. Moscow, p. 88. [in Russian]. 8. Stojlova, L. P. (1999). Matematyka : 
uchebnyk dlya stud. vyssh. ucheb. zaved. [Mathematics: a textbook for students of higher educational institutions]. Moscow, $320 \mathrm{p}$. [in Russian].

9. Tyhonenko, A. V. (2009). Yzuchenye ponyatyya velychyny $v$ nachalnoj shkole [Learning the concept of magnitude in elementary school]. Taganrog, 268 p. [in Russian].

10. Tyhonenko, A., Sarienko, V. \& Chaichenko V. et al. (2018). Velychyny u pochatkovi shkoli : navch.-metod. posibnyk [The values of the cob schools: the fore-method. ambassador]. Slovyansk, 152 p. [in Ukrainian].

11.Urban M.A. (2009). Izuchenie massy i sistemy edinits izmereniya massy na osnove obshchey dlya gruppy osnovnykh velichin modeli [Study of the mass and the system of units of mass measurement onthe basis of the total for the group of basic values]. Primary School, No. 11, pp. 22 - 28. [in Russian].

Стаття надійшла до редакції 12.04.2019

УДК 378.091 .39

DOI:

Ірина Савеліхіна, кандидат медичних наук, доиент кафедри фтизіатрії і пульмонології з курсом професійних хвороб ДВНЗ “Івано-Франківський начіональний медичний університет”

\section{САМОСТІЙНА РОБОТА СТУДЕНТІВ ЯК ОСНОВА ПІЗНАВАЛЬНОЇ ДІЯЛЬНОСТІ У ФОРМУВАННІ ВИСОКОКВАЛІФІКОВАНИХ ФАХІВЦІВ}

У статті обговорюється питання організаиії самостійної роботи студентів з англомовною формою навчання в медичному вузі. Звертається увага на методичні підходи до ї̈ вдосконалення, спрямовані на підвищення якості підготовки лікарів. Останні роки у багатьох медичних закладах вищої освіти Украӥни студенти, інших держав, мають можливість здобути вищу освіту англійською мовою. Така форма навчання є прогресивною та привабливою для великого числа студентів іноземців з різних країн світу.

Ключові слова: самостійна робота; медицина; студенти іноземиі.

Jim. 14.

Iryna Savelikhina, Ph.D.(Medicine), Associate Professor of the Phtisiology and Pulmonology with the Course of Occupational Diseases Department, SHEE "Ivano-Frankivsk National Medical University”

\section{INDEPENDENT WORK AS THE BASIS OF COGNITIVE ACTIVITY IN THE FORMATION OF HIGHLY QUALIFIED SPECIALISTS}

The article discusses the organization of independent work of foreign students. Attention is drawn to the methodological approaches of independent work perfection directed towards increasing the training level of doctors.

Higher education plays an important role in ensuring the training of competent and competitive professionals. Recently, in many medical higher educational institutions of Ukraine, students from other countries have the opportunity to obtain higher education in English. This form of training is quite progressive and attractive for a large number of foreign students from different countries of the world. In modern didactics, independent work of students is considered, on the one hand, as a type of educational work carried out without direct intervention, but under the guidance of a teacher, and on the other, as a means of engaging students into independent cognitive activity, developing their methods of organizing such activity. The effect of independent work of students can be obtained only when it is organized and implemented in the teaching and educational process as an integrated system, permeating all the stages of teaching students in high school. The training of skilled specialists that has the modern theoretical and practical skills, as well as the ability and desire for self-improvement, is the ultimate goal of any pedagogical process. Therefore, the main task of teaching medicine, in particular pulmonology, is the development of clinical thinking by students through the synthesis of profound theoretical knowledge, practical skills and clinical experience.

For the effective organization of independent work of students, the selection of educational material is of great importance. Tasks must be selected based on their practical use in the future profession. The teacher must take into account the substantive content of the disciplines, the level of theoretical preparedness of students, the availability of textbooks in the library collection and the specifics of the social pedagogue's professional activities. Properly organized work stimulates interest, activity, mental activity.

Keywords: independent work; medicine; foreign students.

засвоєнні та поглибленні знань, розвитку ключових компетенцій, як засіб активізації учнів, що $\epsilon$ важливим для формування навичок 